\title{
Kotimaisen valkuaisen käytön taloudelliset edellytykset lihasian ruokinnassa
}

\author{
Jarkko K. Niemi ${ }^{1)}$, Timo Sipiläinen ${ }^{2)}$ ja Timo Karhula ${ }^{1)}$ \\ 1) MTT Taloustutkimus, Latokartanonkaari 9, 00790 Helsinki, Finland, jarkko.niemi@mtt.fi, ti- \\ mo.karhula@mtt.fi \\ 2) Helsingin yliopisto ja MTT Taloustutkimus, Taloustieteen laitos, PL 27, 00014 Helsingin yliopisto, \\ timo.sipilainen@helsinki.fi
}

\section{Tiivistelmä}

Euroopan Unionissa (EU) käytetyistä valkuaispitoisista rehuaineista valtaosa tuodaan EU:n ulkopuolella. Soijarouheessa, joka on keskeinen valkuaisen lähde sikojen ruokinnassa, tuonnin osuus on peräti $98 \%$. EU:n tarve tuoda soijaa säilynee vahvana tämän vuosikymmenen ajan. Viljan ja soijan nimellishinnat ovat korkealla tasolla ja jopa nousevat, mutta soijarouheen hinta voi laskea.

Valkuaisomavaraisuuden nostamiseksi Suomessa on pohdittu keinoja lisätä palkoviljojen (härkäpapu, herne, lupiini) ja öljykasvien viljelyä sekä niiden käyttöä kotieläinten ruokinnassa. Palkoviljojen aminohappokoostumus on kuitenkin sikojen kannalta soijapapua epäedullisempi. Mikäli soijan ruokinnallista arvoa vastaava määrä valkuaista voitaisiin saada edullisemmin kotimaisista valkuaiskasveista, olisi niillä mahdollista korvata tuontisoijaa valkuaisen lähteenä. Peltoviljelyssä valkuaiskasvien viljelyn tulisi antaa muiden kasvien veroinen tai suurempi kate, jotta niiden viljelyyn olisi taloudellinen kannustin.

Tässä tutkimuksessa eri ruokintavaihtoehtojen taloudellisuutta lihasikojen kasvatuksessa tarkastellaan lineaarisella ohjelmoinnilla (LP). LP-mallin tavoitteena on selvittää, mistä rehuaineista saadaan valmistettua edullisin ruokintasuosituksia vastaava rehu oletettujen hintasuhteiden vallitessa. Tutkimuksessa tarkastellaan, millä hinnalla kotimaiset valkuaisrehut ovat kilpailukykyisiä rehuaineita ja miten hintasuhteet vaikuttavat lihasikakohtaiseen katetuottoon. Myös koko tilan katetuotto maksimoidaan LP:llä ottaen huomioon sekä tilan peltoviljely että lihasikojen kasvatus. Tällöin on mahdollista ottaa huomioon valkuaiskasveilla viljelykierrossa saatava hyöty, viljelykasvien erilaiset tuet ja hintaero tilalla tuotetun ja ostetun rehun välillä.

Tulokset viittaavat siihen, että härkäpavun käyttö lihasikojen rehussa olisi taloudellisesti perusteltua, mikäli sen hinta laskisi muutamia prosentteja marras-joulukuun 2011 hintasuhteista muiden hintojen pysyessä ennallaan. Myös rypsirouheen käytölle sikojen rehussa näyttää olevan edellytyksiä, mikäli sen hinta on edullinen. Varteenotettavin vaihtoehto syksyn 2011 hintasuhteilla näyttää kuitenkin olevan soijarouheen korvaaminen rehuherneellä, jota täydennetään rypsirouheella ja härkäpavulla.

Tulokset viittaavat siihen, että suhteellisesti korkea viljan hinta suosii herneen ja härkäpavun käyttöä lihasikojen ruokinnassa, koska tällöin myös kallista viljaa voidaan korvata osittain palkoviljoilla. Jos viljan hinta laskee merkittävästi vuoden 2011 hintatasosta, vähentää se kannustimia käyttää palkoviljoja lihasikojen ruokinnassa, elleivät samalla myös niiden hinnat laske. Mikäli palkoviljojen rehukäyttöä halutaan lisätä, tulisi niiden tarjonnan vahvistua. Viljelykustannusten alentaminen ja tuottovaihtelun vähentäminen ovat avaintekijöitä valkuaisomavaraisuuden nostamiseksi, koska soijarouheen hinta yhdessä viljan hinnan kanssa pitkälti määrittää palkoviljojen kilpailukykyisen hintatason.

Asiasanat: sika, soija, herne, härkäpapu, rypsi, omavaraisuus, rehu, viljely, tuonti, hinta 


\section{Johdanto}

Euroopan Unioni (EU) on maailman suurin valkuaisrouheiden käyttäjä, sillä se kuluttaa lähes neljänneksen maailmassa tuotetuista valkuaisjauhoista ja rouheista. Valtaosa EU:n käyttämästä rehuvalkuaisesta tuodaan Euroopan ulkopuolella. Soijarouheessa, joka on keskeinen valkuaisen lähde sikojen ruokinnassa, tuonnin osuus on peräti $98 \%$. Soijan tuotanto on keskittynyt Etelä- ja Pohjois-Amerikkaan (OECD-FAO 2011). Vielä 1960-luvulla Yhdysvallat tuotti yli $70 \%$ maailman soijasta. Nykyisin se tuottaa enää noin kolmannekseen maailman soijasta ja vuonna 2030 osuuden arvioidaan olevan enää 27\%. Samalla Brasilian ja Argentiinan osuus noussee noin 55\%:in (Masuda ja Goldsmith 2009). Sen sijaan öljykasvien tuotanto ja kulutus ovat EU:ssa paremmin tasapainossa (OECD-FAO 2011).

Suomi on muun Euroopan tavoin riippuvainen tuontivalkuaisesta. Valkuaisomavaraisuuden nostamiseksi Suomessa on pohdittu keinoja lisätä palkoviljojen (härkäpapu, herne, lupiini) ja öljykasvien viljelyä sekä niiden käyttöä kotieläinten ruokinnassa. Valkuaispitoisten rehuaineiden osuus rehukustannuksesta vaihtelee tuotantovaiheittain. Alle 55-kiloisilla lihasioilla valkuaispitoisten rehuaineiden osuus rehukustannuksesta voi vaihdella käytetyistä rehuaineista riippuen noin neljänneksestä yli puoleen, ja isommilla sioilla noin viidenneksestä yli kolmasosaan (Niemi 2011). Suomessa sika saa noin puolet syömästään valkuaisesta viljasta, sillä yleensä vähintään kaksi kolmasosaa sian rehusta on viljaa. Viljan valkuaispitoisuus on kuitenkin matala. Esimerkiksi herneessä ja rypsissä on noin kymmenen prosenttiyksikköä enemmän valkuaista kuin ohrassa (MTT 2011). Myös elintarviketeollisuuden ja biopolttoainetuotannon sivutuotteet sopivat sikojen valkuaisruokintaan, mutta niitä on Suomen markkinoilla saatavissa rajallinen määrä. Parhaana valkuaislähteenä pidetään kuitenkin soijaa, jonka aminohappokoostumus sopii sian ravitsemukseen.

Suomen ilmasto ei suosi soijan viljelyä, joten katseita on käännetty muiden kasvien viljelyn lisäämiseen. Sikojen ruokinnassa varteenotettavia valkuaislähteitä ovat $\mathrm{mm}$. herne, härkäpapu, rypsiöljyn puristuksen sivutuotteet sekä elintarviketeollisuuden prosessien sivutuotteet (Voutila ja Leskinen 2011). Siljander-Rasin ym. (1996) mukaan soijarouhetta voidaan korvata rypsirouheella tuotantotulosten heikkenemättä. Juntin ym. (2005) mukaan rehuherneen viljelyn heikko kannattavuus ja ostoherneen saatavuus ovat esteinä sen käytön lisääntymiselle, sillä sikojen ruokinnassa herne oli kannattava vaihtoehto. Myös hieman uudempi selvitys (Niemi 2009, Partanen 2009) tukee herneen käytön mahdollisuuksia sikojen ruokinnassa. Viime vuosina hernettä on kuitenkin viljelty Suomessa vain muutamien tuhansien hehtaarien alalla. Sen sijaan rypsin viljely on Suomessa melko laajamittaista. Myös härkäpavun viljely on lisääntynyt viime vuosina voimakkaasta ja viljelyala on ylittänyt jo 10000 ha vuodessa (TIKE 2011).

Suomessa ei ole selvitetty, mitkä ovat mahdollisuudet hyödyntää eri valkuaiskasvien yhdistelmiä sikatuotannossa. Mikäli soijan ruokinnallista arvoa vastaava määrä valkuaista voitaisiin saada edullisemmin kotimaisista valkuaiskasveista, niillä olisi mahdollista korvata tuontisoijaa valkuaisen lähteenä. Palkoviljat ovat varteenotettava vaihtoehto myös silloin, kun halutaan käyttää geenimuuntelematonta rehua. Peltoviljelyssä valkuaiskasvien viljelyn tulisi antaa muiden kasvien veroinen tai suurempi kate, jotta niiden viljelyyn olisi kannustin. Tämän tutkimuksen tavoitteena olikin selvittää, millaiset ovat keskeisten rehuaineiden markkinanäkymät EU:ssa ja onko sikatuotannossa taloudellisia edellytyksiä korvata soijarouhetta herneellä, härkäpavulla tai rypsirouheella.

\section{Aineisto ja menetelmät}

Tutkimukseen sisältyi kolme vaihetta. Ensimmäisessä vaiheessa tarkasteltiin maailmanmarkkinoiden kehitystrendejä viimeisen vuoden aikana julkaistujen markkina-analyysien avulla (OECD-FAO 2011, Fapri 2011, EU:n komissio 2010, USDA 2011). Vaiheen tavoitteena oli kartoittaa, miten valkuaiskasvien ja rehuaineiden markkinatilanteen odotetaan muuttuvan lähivuosina, sekä luoda näkemyksiä mallinnettavista skenaarioista. Tarkastelussa keskityttiin lihasikojen kasvatuksessa keskeisten maataloustuotteiden (sianliha, öljy- ja valkuaiskasvit, viljat) hintoihin, tuotantoon ja kulutukseen.

Tutkimuksen toisessa vaiheessa tarkasteltiin rehujen markkinahintojen vaikutusta lihasikakohtaiseen katetuottoon. Excel-taulukkolaskentaohjelmalla laadittiin lineaarisen ohjelmoinnin (LP) malli, jonka tavoitteena oli minimoida rehuyksikön hinta lihasikojen kolmelle eri rehuseokselle. Malli normeerattiin siten, että se laski 9,3 MJ nettoenergiaa sisältävän rehuannoksen hinnan. Näin voitiin selvittää, mistä rehuaineista saadaan valmistettua edullisimmin ruokintasuosituksia vastaava rehu.

LP:n tavoiteyhtälö oli seuraava: 


$$
\begin{aligned}
& \min C_{f}=\sum_{i=1}^{n} p_{i o} y_{i o} \\
& \text { siten että } \quad 0 \geq y_{i o} \geq y_{i, \max } \text { kaikille } i \\
& y_{\text {rypsi,o }}+y_{\text {herne }, o}+y_{\text {härkäpapu,o }} \leq z_{M J} \\
& \\
& \quad P_{f, \text { ami }} \geq \sum_{i=1}^{n} y_{i o} z_{i, \text { ami }} \geq P_{f, \text { ami } \max } \text { kaikille ami. }
\end{aligned}
$$

jossa $C_{f}$ on 9,3 MJ nettoenergiaa sisältävän rehun $f$ hinta, $i=1, \ldots, n$ on käytettävissä olevien rehuaineiden joukko, $p_{i o}$ on rehuaineen $i$ (osto)hinta, $y_{i o}$ on rehuaineen $i$ (osto)määrä, $y_{i, m a x}$. on rehuaineen $i$ enimmäisosuus rehun f energiasisällöstä, $z_{M J}$ on rypsirouheen, herneen ja härkäpavun yhteenlaskettu enimmäisosuus rehun energiasta, $P_{f, a m i}$ on aminohapon $a m i$ vähimmäismäärä rehussa $f$ yhteensä, $z_{i, a m i}$ on aminohapon ami määrä rehuaineessa $i$ ja $P_{f, a m i, m a x}$ on aminohapon ami suurin sallittu enimmäismäärä rehussa $f$. Kullekin kotimaiselle valkuaisaineelle oletettiin $P_{\text {f,ami,max }}=20 \%$ ja lisäksi $z_{M J}=30 \%$.

Mallinnetun rehun $f$ aminohappokoostumuksen oletettiin täyttävän suomalaiset ruokintasuositukset. Lähtötilanteessa ohran hinnaksi oletettiin $160 € / t$, soijarouheen $400 € / t$, härkäpavun $245 € / t$, rypsirouheen $235 € / t$ ja herneen $200 € / t$. Lisäksi rehuun voitiin käyttää synteettisiä aminohappoja ja muita pienkomponentteja. Minimoituja rehujen hintoja käyttäen tarkasteltiin, miten kolmivaiheruokinnalla ruokittujen lihasikojen katetuotto muuttuu, kun viljan ja valkuaispitoisten rehuaineiden hinnat nousevat tai laskevat enimmillään $20 \%$ lähtötilanteesta. Yhdessä skenaariossa rouheiden, viljan ja palkoviljojen hintoja muutettiin samanaikaisesti taulukon 2 hintamuutoksia mukaillen.

Tutkimuksen kolmannessa vaiheessa tarkasteltiin koko tilan taloudellista ylijäämää eri ruokintavaihtoehtojen LP-mallilla. Tällöin maksimoitiin koko lihasikatilan katetuotto ottaen huomioon sekä tilan peltoviljely että lihasikojen kasvatus. Esimerkkitilalla oli 140 ha peltoa ja se tuotti 2400 lihasikaa vuodessa. Tilan tavoitteeksi oletettiin maksimoida sianlihantuotannon ja peltoviljelyn yhdistelmän katetuotto, joka saadaan vähentämällä tuotoista (myyntituotot ja tuet) muuttuvat ja työkustannukset. Kasvituotteiden myynti ja ostaminen oli mahdollista. Tila voi valita ruokintavaihtoehdoista 1) ohra-soijarouhe, 2) ohra-herne-soijarouhe, 3) ohra-härkäpapu-soijarouhe tai 4) ohra-rypsi-soijarouhe synteettisillä aminohapoilla täydennettynä. Lisäksi oletettiin, että suositusten mukaan ruokittaessa kaikilla vaihtoehdoilla saavutetaan sama tuotos. Herneen, härkäpavun ja rypsirouheen osuus ruokinnassa rajoitettiin $20 \%$ :in ruokintaan liittyvien haittavaikutusten ehkäisemiseksi erillisissä ruokintamalleissa. Hintaoletukset olivat samat kuin sianlihantuotannon tarkastelussa. Sianlihan hinnaksi oletettiin $1,5 € / \mathrm{kg}$ ja porsaan hinnaksi $56 € / \mathrm{kpl}$. Viljelykasvien hehtaarisadoiksi oletettiin ohralla $4000 \mathrm{~kg} / \mathrm{ha}$, herneellä 3000 kg/ha, härkäpavulla 2500 kg/ha ja rypsillä 2000 kg/ha. LP-ongelma on:

$$
\begin{aligned}
& \max \pi=\sum_{j=1}^{4}\left[\left(p_{s} y_{s}\right) s_{j}+T_{z} s_{j}+L a_{s} s_{j}\right. \\
&\left.-C_{s} s_{j}\right]-\sum_{i=1}^{6} p_{i o} y_{i o}+\sum_{i=1}^{4}\left[p_{i m}\left(y_{i} a_{i}-y_{i r}+y_{i 0}\right)+a_{i} T_{i}\right] \\
&-\sum_{i=1}^{4} c_{i} a_{i}+\sum_{i=1}^{2} J V_{i} a_{i}
\end{aligned}
$$

siten että

$$
\begin{aligned}
& A \leq \sum_{i=1}^{4} a_{i}, \quad S \leq \sum_{j=1}^{4} s_{j}, \\
& \mathrm{~L} \leq \sum_{i=1}^{4} l_{i}+\sum_{j=1}^{4} l_{j} \\
& y_{i r}=y_{i} a_{i}-y_{i m}+y_{i o^{3}} \\
& 0,2 A \geq \sum_{i=1}^{2} a_{i j} \\
& 0,2 A \geq a_{3} \\
& 40 \geq \sum_{i=1}^{3} a_{i}
\end{aligned}
$$


jossa $\mathrm{s}_{\mathrm{j}}$ on lihasikojen määrä kullakin ruokinnalla, $y_{s}$ on sian teuraspaino, $p_{s}$ on sianlihan hinta, $p_{i o}$ on kunkin rehun/kasvin ostohinta, $p_{i m}$ myyntihinta. $T_{s}$ on kotieläintuki laskettuna tuotettua lihasikaa kohti ja $T_{i}$ kunkin kasvin tuki. $L a$ on lannan nettoarvo sikaa kohti. $C_{s}$ on puolestaan sianlihantuotannon muuttuvat kustannukset ilman rehukustannusta. $C_{i}$ on kunkin kasvin viljelyn muuttuva kustannus ja $\mathrm{JV}_{\mathrm{i}}$ herneen ja härkäpavun jälkivaikutus arvioituna $30 \mathrm{~kg}$ :ksi typpeä per hehtaari. $A$ on kokonaispeltoala (ha), $a_{i}$ on kunkin kasvin viljelyala, $S$ on sikapaikkojen lukumäärä kerrottuna kiertonopeudella, $L$ on työpanos (h), jossa $l_{i}$ on kunkin kasvin ja $l_{j}$ yhden lihasian vaatima työmäärä, $y_{i r}$ on kunkin kasvin rehukäyttö, jossa $y_{i}$ on hehtaarisato $(\mathrm{kg}), y_{i m}$ on kasvin myyntimäärä ja $y_{i o}$ on ostomäärä. Kolme viimeistä epäyhtälöä rajoittavat herneen, härkäpavun ja rypsin viljelyn osuutta peltoalasta.

Mallilla maksimoidaan lihasian kasvatuksen tilakohtaista katetta eri ruokintavaihtoehtojen puitteissa siten, että otetaan huomioon tilan peltoviljely lihasian kasvatuksen lisäksi. Tällöin on mahdollista ottaa huomioon myös valkuaiskasvien viljelystä saatava hyöty viljelykierrossa sekä niille saatu korkeampi tuki. Jatkossa voidaan lisäksi arvioida eri kasvien viljelyn riskiä suhteessa muihin kasveihin ja sen vaikutusta esimerkiksi riskiä karttavan päätöksentekijän valintoihin.

\section{Tulokset ja tulosten tarkastelu}

\section{Tuotannon, kulutuksen ja markkinahintojen kehitys 2010-luvulla}

Markkinakatsausten (OECD-FAO 2011, Fapri 2011, EU:n komissio 2010) mukaan valkuaispitoisten kasvien tuotanto lisääntyy sekä EU:ssa että koko Euroopassa tällä vuosikymmenellä. Öljykasvien kokonaistuotannon arvioidaan lisääntyvän EU:ssa tällä vuosikymmenellä runsaat $14 \%$. Myös rypsi-, rapsi- ja soijarouheiden ja -jauhojen tuotannon odotetaan lisääntyvän. Euroopan valkuaisomavaraisuus ei silti juurikaan lisäänny vuoteen 2020 mennessä, koska myös valkuaisen kulutus lisääntyy. Samanaikaisesti sekä viljojen että sianlihan tuotannon ja kulutuksen odotetaan lisääntyvän. Niitä Eurooppa tuottaa yli oman kulutuksensa (Taulukko 1).

Tuotannon ja kulutuksen muutosten vuoksi Euroopan tarve tuoda valkuaista säilyy suunnilleen nykyisellä tasolla tällä vuosikymmenellä, joskin tutkimusten ennusteet poikkeavat tässä hieman toisistaan. Sen sijaan viljojen vientitarpeen on arvioitu lisääntyvän (Taulukot 1 ja 3). Osa vilja-alasta olisikin perusteltua ohjata valkuaiskasvien viljelyyn.

Taulukon 1 mukaan Eurooppa säilyy vahvana vehnän- ja rapsintuotantoalueena ja myös sen kulutusosuus maailmassa tuotetusta valkuaisesta säilyy suurena. Kilpailu viljelysmaasta kuitenkin kiristyy, koska biopolttoaineiden tuotanto kasvaa jopa kaksin-kolminkertaiseksi nykyisestä mm. EU:n politiikkatoimenpiteiden seurauksena (EU:n komissio 2010).

Biopolttoaineiden tuotannon lisääntymisen on arvioitu laskevan valkuaispitoisten jauhojen ja rouheiden hintoja. Vuosien 2009-10 ja 2020 välillä niiden hintojen arvioidaan laskevan 6-10 \%, koska biopolttoaineiden valmistuksen sivutuotteena markkinoille tulee runsaasti valkuaispitoisia rehuaineita. Sen sijaan soijapavun ja rypsin/rapsin tuottajahintojen on arvioitu nousevan muutamia prosentteja, mikä voi johtua näiden kasvien sisältämistä energiakomponenteista (mm. öljyt) (Taulukko 2). Faprin mukaan myös viljojen ja sianlihan hinnat nousisivat EU:ssa. On mahdollista, että soijapavun ja sianlihan hintojen nousu heijastuu rypsin ja palkoviljojen hintoihin nostaen niitä hieman.

\section{Herne, härkäpapu ja rypsirouhe rehussa}

Tutkimuksen toisessa vaiheessa tarkasteltiin rehuaineiden käyttösuhteita rehussa ja rehun hintaa. Taulukossa 4 on esitetty 13 eri skenaarion tulokset, mukaan lukien sialle syötetyn rehun hinta ja koostumus keskimäärin kaikissa kolmessa ruokintavaiheessa. LP-malli valitsi viljan ja soijarouheen rinnalle rehuun ensisijaisesti hernettä ja rypsirouhetta. Herne ja rehuohra sisältyivät rehuun kaikilla taulukossa 4 tarkastelluilla hintasuhteilla, mikäli se oli asetettujen rajoitteiden puitteissa mahdollista. Taulukkoa 4 varten tehdyssä tarkastelussa rypsirouheen ja palkoviljojen enimmäisosuus rajoitettiin 20 prosenttiin rehun energiasta. Mikäli palkoviljoja ja rypsirouhetta ei ollut saatavilla (skenaario B), tuottajalle aiheutuva tulonmenetys oli runsaat kaksi euroa lihasikaa kohti. Mikäli soijarouhetta ei olisi saatavilla, tuottajalle aiheutuva menetys oli noin 60 senttiä lihasikaa kohti.

Yksittäisen valkuaisrehuaineen hinnan laskiessa $20 \%$ katetuotto nousi 1,1-1,9€ lihasikaa kohti, ja useimmissa tapauksissa hintamuutos lisäsi merkittävästi kyseisen rehuaineen osuutta rehussa (skenaariot C-G). Tulos on ehdollinen rajoituksille, joita asetettiin rehuaineiden käyttömäärille. LP-malli viittaa siihen, että härkäpavun käyttö lihasikojen rehussa muuttuisi taloudellisesti perustelluksi, mikäli sen hinta laskisi muutamia prosentteja skenaarion A hintasuhteista muiden hintojen pysyessä ennal- 
laan. Myös rypsirouheen hinnan laskiessa kannustin sen käytön lisäämiseen kasvoi. Mikäli rouheiden hinnat laskisivat $10 \%$ ja viljojen ja palkoviljojen hinnat nousisivat $5 \%$ (skenaario $\mathrm{H}$ ), katetuotto laski euron lihasikaa kohti ja viljoja, palkoviljoja ja soijarouhetta korvattaisiin rypsirouheella.

Taulukko 1. Viljojen, valkuaiskas vien ja sianlihan tuotanto- ja kulutus Euroopassa/EU:ssa sekä tuotanto (milj. tonnia) koko maailmas sa vuosina 2000, 2009-10 ja 2020 (ennuste) kolmen eri tutkimusarvion (OECD, FAPRI ja EU:n komissio) mukaan sekä muutos vuosista 2009-10 vuoteen 2020.

\begin{tabular}{|c|c|c|c|c|c|c|c|c|c|c|c|c|}
\hline \multirow{3}{*}{ OECD } & \multicolumn{4}{|c|}{ Tuotanto (Eurooppa) } & \multicolumn{4}{|c|}{ Kulutus (Eurooppa) } & \multicolumn{4}{|c|}{ Tuotanto (koko maailma) } \\
\hline & \multicolumn{2}{|c|}{$20002009-10$} & \multicolumn{2}{|c|}{2020 Muutos } & \multicolumn{2}{|c|}{$20002009-10$} & \multicolumn{2}{|c|}{2020 Muutos } & \multicolumn{2}{|c|}{$20002009-10$} & \multicolumn{2}{|c|}{2020 Muutos } \\
\hline & & & & & & & & & & & & \\
\hline Vehnä & & 216 & 253 & $17,2 \%$ & & 189 & 205 & $8,5 \%$ & & 668 & 746 & $11,6 \%$ \\
\hline Viljat pl. vehnä ja riisi & & 212 & 243 & $14,8 \%$ & & 204 & 230 & $12,3 \%$ & & 1119 & 1321 & $18,0 \%$ \\
\hline Öljykas vit & & 50 & 64 & $27,8 \%$ & & 64 & 75 & $16,1 \%$ & & 431 & 507 & $17,8 \%$ \\
\hline Valkuaispitoiset jauhot & & 34 & 38 & $14,6 \%$ & & 60 & 68 & $13,7 \%$ & & 249 & 297 & $19,3 \%$ \\
\hline Sianliha, ruhopainoa & & 26 & 29 & $9,0 \%$ & & 26 & 28 & $9,5 \%$ & & 107 & 127 & $18,6 \%$ \\
\hline FAPRI & \multicolumn{4}{|c|}{ Tuotanto (EU) } & \multicolumn{4}{|c|}{ Kulutus (EU) } & & & & \\
\hline Vehnä & 132 & 137 & 156 & $13,4 \%$ & 136 & 137 & 154 & $12,3 \%$ & 585 & 659 & 724 & $9,9 \%$ \\
\hline Ohra & 60 & 57 & 62 & $7,9 \%$ & 65 & 68 & 65 & $-4,3 \%$ & 133 & 131 & 159 & $22,1 \%$ \\
\hline Soijapapu & 1 & 1 & 1 & $9,2 \%$ & 20 & 15 & 14 & $-5,8 \%$ & 175 & 259 & 294 & $13,4 \%$ \\
\hline Soijarouheet & 13 & 10 & 9 & $-10,4 \%$ & 32 & 32 & 33 & $0,7 \%$ & 116 & 171 & 204 & $19,4 \%$ \\
\hline Rapsi/rypsi & 11 & 21 & 24 & $15,4 \%$ & 12 & 25 & 28 & $14,3 \%$ & 38 & 60 & 70 & $17,4 \%$ \\
\hline Rapsi/rypsirouheet & 6 & 13 & 15 & $16,5 \%$ & 6 & 13 & 15 & $16,6 \%$ & 21 & 34 & 39 & $15,1 \%$ \\
\hline Sianliha, ruhopainoa & 21 & 22 & 23 & $2,6 \%$ & 20 & 21 & 21 & $2,8 \%$ & & & & \\
\hline \multicolumn{13}{|l|}{ EU:n komissio } \\
\hline Vehnä & & 137 & 152 & $11,0 \%$ & & 127 & 138 & $8,7 \%$ & & & & \\
\hline Viljat pl. Vehnä ja riisi & & 150 & 161 & $6,7 \%$ & & 152 & 163 & $7,4 \%$ & & & & \\
\hline Ohra & & 58 & 59 & $1,3 \%$ & & 55 & 55 & $0,5 \%$ & & & & \\
\hline Öljykasvit & & 29 & 33 & $14,1 \%$ & & 45 & 50 & $10,6 \%$ & & & & \\
\hline Öljykasvien jauhot ja ro & ouheet & 26 & 29 & $10,6 \%$ & & 50 & 55 & $8,2 \%$ & & & & \\
\hline Sianliha, ruhopainoa & & 22 & 24 & $6,6 \%$ & & 21 & 22 & $8,5 \%$ & & & & \\
\hline
\end{tabular}

Taulukko 2. Kolmen tutkimuslaitoksen arviot viljojen, valkuaislähteiden ja sianlihan hintojen kehityksestä maailmanmarkkinoilla (OECD), Euroopassa (IFPRI) ja Yhdysvalloissa vuosina 2000-2020 sekä hintamuutos vuosista 2009-10 vuoteen 2020.

\begin{tabular}{|c|c|c|c|c|c|}
\hline Maataloustuote ja ennustaja & Selite & 2000 & $2009-10$ & 2020 & Muutos \\
\hline \multicolumn{6}{|l|}{ OECD } \\
\hline Vehnä & M & & 262 & 240 & $-8,2 \%$ \\
\hline Viljat pl. vehnä ja riisi & M & & 210 & 203 & $-3,6 \%$ \\
\hline Öljykasvit & M & & 464 & 478 & $3,0 \%$ \\
\hline Valkuaispitoiset jauhot & M & & 366 & 328 & $-10,4 \%$ \\
\hline Sianliha, ruhopainoa & M & & 1474 & 1860 & $26,1 \%$ \\
\hline \multicolumn{6}{|l|}{ FAPRI } \\
\hline Vehnä & EU, tuottajahinta & 116 & 193 & 196 & $1,7 \%$ \\
\hline Ohra & M, FOB vientihinta & 84 & 185 & 199 & $7,5 \%$ \\
\hline Soijapapu & $\mathrm{R}, \mathrm{CIF}$ tuontihinta & 200 & 452 & 477 & $5,4 \%$ \\
\hline Soijarouheet & $\mathrm{R}, \mathrm{CIF}$ tuontihinta & 188 & 397 & 371 & $-6,3 \%$ \\
\hline Rapsi/rypsi & $\mathrm{H}, \mathrm{FOB}$ vientihinta & 202 & 463 & 484 & $4,5 \%$ \\
\hline Rapsi/rypsirouheet & $\mathrm{R}, \mathrm{CIF}$ tuontihinta & 141 & 229 & 201 & $-12,2 \%$ \\
\hline Sianliha, ruhopainoa & USA & & 982 & 1189 & $33,7 \% *$ \\
\hline \multicolumn{6}{|l|}{ USDA } \\
\hline Viljojen tuottajahintaindeksi & USA & & 181,5 & 194,8 & $7,3 \%$ \\
\hline Öljykasvien tuottajahintaindeksi & USA & & 175,0 & 185,2 & $5,8 \%$ \\
\hline Teuraseläinten tuottajahintaindeksi & USA & & 114,5 & 149,9 & $30,9 \%$ \\
\hline
\end{tabular}

$\mathrm{M}=$ maailmanmarkkinahinta, $\mathrm{R}=$ Rotterdam, $\mathrm{H}=$ Hampuri, USA=Yhdysvaltain hinta 
Taulukko 3. Yhdysvaltain maatalousministeriön arvio viljojen, valkuaislähteiden ja sianlihan tuonti- ja vientimäärien kehityksestä EU:ssa 2009 - 2020

\begin{tabular}{lrrrrrr}
\hline & \multicolumn{7}{c}{ Tuonti } & \multicolumn{1}{c}{ Vienti } \\
Tuote & $2009-10$ & 2020 & Muutos & $2009-10$ & 2020 & Muutos \\
\hline Vehnä & 5,5 & 7,0 & $27 \%$ & 22,1 & 20,8 & $-5,5 \%$ \\
Viljat, pl. vehnä ja riisi & 4,0 & 3,3 & $-18 \%$ & 4,5 & 8,8 & $96,0 \%$ \\
Ohra & 2,9 & 5,2 & $81 \%$ & 0,1 & 0,3 & $158,0 \%$ \\
Rypsi ja rapsi & 2,1 & 5,3 & $152 \%$ & & & \\
Soijapapu & 13,2 & 11,5 & $-13 \%$ & 0,1 & 0,3 & $158,0 \%$ \\
\hline
\end{tabular}

Taulukko 4. Viljan, soija- ja rypsirouheen ja palkoviljojen hintojen (€/t) vaikutus katetuottoon (€/lihasika**) sekä 3-vaiheruokinnan rehujen koostumukseen keskimäärin. Muuttuva hinta on harmaalla värillä.

\begin{tabular}{lrrrrrrrrrrrrr}
\hline Skenaario & $\mathrm{A}$ & $\mathrm{B}$ & $\mathrm{C}$ & $\mathrm{D}$ & $\mathrm{E}$ & $\mathrm{F}$ & $\mathrm{G}$ & $\mathrm{H}$ & $\mathrm{I}$ & $\mathrm{J}$ & $\mathrm{K}$ & $\mathrm{L}$ & $\mathrm{M}$ \\
\hline Ohran hinta $€ / \mathrm{t}$ & 160 & 160 & 128 & 160 & 160 & 160 & 160 & 168 & 160 & 192 & 160 & 96 & 160 \\
Soijarouheen hinta $€ / \mathrm{t}$ & 400 & 400 & 400 & 320 & 400 & 400 & 400 & 360 & 400 & 400 & 320 & 400 & 400 \\
Härkäpavun hinta $€ / \mathrm{t}$ & 245 & 245 & 245 & 245 & 196 & 245 & 245 & 257 & 196 & 245 & 196 & 245 & 245 \\
Rypsirouheen hinta $€ / \mathrm{t}$ & 235 & 235 & 235 & 235 & 235 & 188 & 235 & 212 & 235 & 235 & 188 & 235 & 235 \\
Herneen hinta $€ / \mathrm{t}$ & 200 & 200 & 200 & 200 & 200 & 200 & 160 & 210 & 160 & 200 & 160 & 200 & 200 \\
Rehun koostumus & & & & & & & & & & & & & \\
Viljaa & $71 \%$ & $86 \%$ & $72 \%$ & $72 \%$ & $66 \%$ & $66 \%$ & $71 \%$ & $66 \%$ & $66 \%$ & $66 \%$ & $65 \%$ & $86 \%$ & $68 \%$ \\
Soijarouhetta & $7 \%$ & $14 \%$ & $8 \%$ & $8 \%$ & $3 \%$ & $3 \%$ & $7 \%$ & $3 \%$ & $3 \%$ & $3 \%$ & $3 \%$ & $14 \%$ & $0 \%$ \\
Härkäpapua & $2 \%$ & $0 \%$ & $0 \%$ & $0 \%$ & $11 \%$ & $0 \%$ & $2 \%$ & $0 \%$ & $11 \%$ & $11 \%$ & $2 \%$ & $0 \%$ & $5 \%$ \\
Rypsirouhetta & $0 \%$ & $0 \%$ & $0 \%$ & $0 \%$ & $0 \%$ & $12 \%$ & $0 \%$ & $12 \%$ & $0 \%$ & $0 \%$ & $10 \%$ & $0 \%$ & $10 \%$ \\
Hernettä & $20 \%$ & $0 \%$ & $20 \%$ & $20 \%$ & $20 \%$ & $19 \%$ & $20 \%$ & $19 \%$ & $20 \%$ & $20 \%$ & $19 \%$ & $0 \%$ & $16 \%$ \\
Tuottovaikutus, $€ /$ lihasika*** & $-2,1$ & 5,6 & 1,6 & 1,1 & 1,2 & 1,9 & $-1,0$ & 3,1 & $-5,4$ & 3,8 & 11,5 & $-0,6$ \\
\hline
\end{tabular}

*Skenaariossa B ei ole saatavilla hernettä, härkäpapua tai rypsirouhetta ja skenaariossa M ei soijarouhetta.

**Mikäli vaikutus on nolla euroa, silloin kate on sama kuin skenaariossa A.

Mikäli soija korvattaisiin skenaariossa A härkäpavulla, ja härkäpavun hinta laskisi $6 \%$, päästäisiin samaan katetuottoon kuin skenaariossa A. Yksityiskohtaisempi tarkastelu osoittikin, että viime vuosien hintasuhteilla härkäpavun käyttömäärä rehussa vaikutti melko maltillisesti rehun hintaan. Härkäpavun käytöstä saatava hyötyä olisi myös se, että riippuvuus tuontisoijasta vähenisi. Härkäpapua suurempi potentiaali soijarouheen korvaajana näyttää kuitenkin olevan rehuherneellä. Herneen käytön kannattavuutta heikensivät ohran ja soijan hinnan lasku. Herneen tai härkäpavun osuuden lisääminen rehuseoksessa vähensi voimakkaasti soijan käyttöä, mutta samalla myös ohran osuus rehussa väheni. Tästä ominaisuudesta voi olla hyötyä, mikäli viljan hinta on nousee vielä korkeammaksi suhteessa valkuaispitoisten rehuaineiden hintoihin (skenaariot $\mathrm{J}$ ja $\mathrm{K}$ ). Myös rypsirouheen käytölle sikojen rehussa näyttäisi olevan edellytyksiä, mikäli se on hinnaltaan riittävän edullista.

\section{Herne, härkäpapu ja rypsi koko tilan näkökulmasta}

Palkoviljojen kohdalla on kuitenkin tärkeää huomioida myös niiden vaikutus viljelykierrossa. Tämä vaatii tilatason tarkastelua. Mikäli rehuaineet arvotetaan peltoviljelyn kustannusten mukaan, voi tulos muuttua, koska tällöin ruokintaa suunnitellaan osana tilakokonaisuutta. Palkoviljat voivat esimerkiksi olla ohralle kilpailukykyinen viljelyvaihtoehto. Peltoviljelyssä palkoviljojen etuina ovat niiden typensidontakyky ja vähäinen lannoitustarve. Toisaalta siemenkustannus voi olla jopa $70 \%$ palkoviljan viljelyn muuttuvista kustannuksista (Juntti ym. 2005). Rypsillä lannoitus aiheuttaa palkoviljoja suuremman osan kustannuksista, mutta sillä siementarve on vähäinen.

Myös tilakohtaisessa tarkastelussa hernettä tai rypsirouhetta sisältävät rehuvaihtoehdot osoittautuivat suurimman katteen tuottaviksi. Ero näiden vaihtoehtojen välillä oli reilut puoli euroa lihasikaa kohti ohra-hernerehun hyväksi. Kustannusero ohra-soijarouheruokintaan verrattuna oli noin 2,5 euroa 
ja ohra-härkäpapurehuun verrattuna noin 1,5 euroa lihasikaa kohti. Kun ruokinnassa käytetään ohraherneseosta, ostorehuherneen määrä on merkittävä. Jos rehuherneen hinta nousee härkäpavun hinnan tasolle, lihasian ruokinta muuttuu ohra-rypsirouhepohjaiseksi, mutta hernettä viljellään myytäväksi viljelykierron sallimissa rajoissa.

Tilatason kate-erot ruokintojen välillä ovat pieniä, kun ne suhteutetaan sianlihan hintaan. Jos vain ohralla ja herneellä ruokitun sian lihan hinta laskee vajaan sentin per kg (ceteris paribus), ruokinta vaihtuu ohra-rypsirouhepohjaiseksi. Vajaat kolme senttiä korkeampi hinta tai vastaavasti parempi kasvu ohra-soijaruokinnalla johtaisi sen valintaan. Ohra-härkäpapuruokinnan valintaan riittäisi pari senttiä korkeampi lihan hinta.

\section{Johtopäätökset}

Tutkimusten mukaan EU:n tarve tuoda soijaa ja muita kasveja valkuaisrehuiksi säilyy vahvana tämän vuosikymmenen ajan. Viljan ja soijan nimellishinnat kuitenkin säilynevät korkealla tasolla ja hieman jopa nousevat. Sen sijaan soijarouheen hinta voi jopa laskea.

Tulokset viittaavat siihen, että sikojen ruokinnassa on hyvät mahdollisuudet korvata soijarouhetta palkoviljoilla ja rypsirouheella. Etenkin korkea viljan hinta suosii herneen ja härkäpavun käyttöä lihasikojen ruokinnassa, koska tällöin myös kallista viljaa voidaan korvata osittain palkoviljoilla. Jos viljan hinta tulevaisuudessa laskisi merkittävästi vuoden 2011 hintatasosta, vähentäisi se kannustimia käyttää palkoviljoja lihasikojen ruokinnassa, elleivät samalla myös niiden hinnat laskisi. Viljan hinnalla on myös suuri vaikutus lihasikakohtaiseen katetuottoon, sillä yli puolet lihasian rehusta on viljaa.

Tulokset viittaavat siihen, että peltoviljelyn kustannusten alentaminen ja tuottovaihtelun vähentäminen ovat avaintekijöitä valkuaisomavaraisuuden nostamiseksi, sillä rehu tulisi tuottaa alle markkinahintojen. Tämä edellyttänee sekä korkeaa hehtaarisatoa että edullista viljelyteknologiaa. Lisäksi palkoviljojen osalta haasteena on satoriskin hallinta, koska niitä pidetään riskialttiina kasveina viljellä. Hintalisän saaminen joko valkuaiselle tai sianlihalle ei paranna kotimaisen valkuaisen kilpailukykyä rehuaineena suhteessa soijarouheeseen, mikäli soijarouheen hinta maailmanmarkkinoilla ei samalla nouse. Eräs madollisuus palkoviljojen saatavuuden parantamiseksi on tilojen välinen yhteistyö (esim. ostorehutuotanto) erikoistumis- ja mittakaavaetujen saavuttamiseksi.

\section{Kirjallisuus}

Euroopan komissio. 2010. Prospects for agricultural markets and income in the EU 2010 - 2020. 78 p. European Commission, Directorate-General for Agriculture and Rural Development, Brussels. Saatavilla Internetissä: http://ec.europa.eu/agriculture/publi/caprep/prospects2010

Fapri. 2011. FAPRI-ISU 2011 world agricultural outlook database. Saatavilla Internetissä:

http://www.fapri.iastate.edu/tools/outlook.aspx

Juntti, L. Pihamaa, P. \& Heikkilä, A.-M. 2005. Kotimaista valkuaista herneestä - Onko viljelyyn taloudellisia edellytyksiä? MTT:n selvityksiä 93. http://www.mtt.fi/mtts/pdf/mtts93.pdf

Masuda, T. \& Goldsmith, P.D. 2009. World soybean production: area harvested, yield, and long-term projections. International Food and Agribusiness Management Review 12: 143-162.

MTT. 2011. Rehutaulukot ja ruokintasuositukset. Saatavilla Internetissä: http://www.mtt.fi/rehutaulukot

Niemi, J. 2009. Edullisella herneellä säästöä rehukustannuksiin. Sika 39 (1): 25-27.

Niemi, J. 2011. Valkuaisrehujen taloudellinen käyttö: Sianlihantuotanto. Teoksessa: Aaltonen, R. \& Peltonen, S. (toim.). Valkuaisrehujen tuotanto ja käyttö. Tieto tuottamaan 134. ProAgria Keskusten Liiton julkaisuja 1108.

ProAgria Keskusten Liitto, Vantaa. s. 14-18.

OECD-FAO 2011. OECD-FAO Agricultural Outlook 2011-2020. Database. Saatavilla Internetissä:

http://www.agri-outlook.org

Partanen, K. 2009. Herne ja härkäpapu maittavat. Sika 39 (1): 22-27.

Siljander-Rasi, H., Valaja, J. Alaviuhkola, Rantamäki, P. \& Tupasela, T. 1996. Replacing soya bean meal with heat-treated, low-glucosinolate rapeseed meal does not affect the performance of growing-finishing pigs. Animal Feed Science Technology 60: 1-12.

TIKE. 2011. Maataloustilastot. Saatavilla Internetissä: www.maataloustilastot.fi

USDA. 2011. USDA agricultural projections report (OCE-2011-1). Long-term agricultural projection tables. Saatavilla Internetissä: www.ers.usda.gov/briefing/projections

Voutila, L. \& Leskinen, U.-M. 2011. Valkuaisrehut sian ruokinnassa. Teoksessa: Aaltonen, R. \& Peltonen, S. (toim.). Valkuaisrehujen tuotanto ja käyttö. Tieto tuottamaan 134. ProAgria Keskusten Liiton julkaisuja 1108. ProAgria Keskusten Liitto, Vantaa. s. 82-91. 